\title{
Historical biogeography and speciation in the Creole wrasses (Labridae, Clepticus)
}

\author{
Ricardo Beldade · J. B. Heiser · D. R. Robertson • \\ J. L. Gasparini $\cdot$ S. R. Floeter $\cdot$ G. Bernardi
}

Received: 10 April 2008 / Accepted: 16 December 2008 / Published online: 1 January 2009

(C) The Author(s) 2008. This article is published with open access at Springerlink.com

\begin{abstract}
We tested whether vicariance or dispersal was the likely source of speciation in the genus Clepticus by evaluating the evolutionary timing of the effect of the mid-Atlantic barrier, which separates $C$. brasiliensis and C. africanus, and the Amazon barrier, which separates C. parrae and $C$ brasiliensis. Genetic data from three mitochondrial genes and one nuclear gene were used. Mitochondrial genes separated Clepticus into three well supported clades corresponding to the three recognized allopatric morpho-species. All analyses provided consistent support for an initial separation ( 9.68 to 1.86 mya; $4.84 \%$ sequence divergence) of the Caribbean and South Atlantic lineages, followed by a much more recent divergence
\end{abstract}

Communicated by M.I. Taylor.

R. Beldade $(\bowtie) \cdot$ G. Bernardi

Department of Ecology and Evolutionary Biology,

University of California, Santa Cruz, CA 95060, USA

e-mail: ricardobeldade@yahoo.com

\section{J. B. Heiser}

Department of Ecology and Evolutionary Biology,

Stimson Hall, Cornell University, Ithaca, NY 14853, USA

D. R. Robertson

Smithsonian Tropical Research Institute,

Panama, Unit 0948, APO AA 34002, USA

\section{J. L. Gasparini}

Departamento de Ecologia e Recursos Naturais,

Universidade Federal do Espírito Santo,

Vitória, ES 29060-900, Brazil

\section{S. R. Floeter}

Departamento de Ecologia e Zoologia, Universidade Federal de Santa Catarina,

Florianopolis, SC 88010-970, Brazil
( $\sim 0.60$ to 0.12 mya; $0.3 \%$ sequence divergence) of the Brazilian and African sister morpho-species. Both these phylogenetic events occurred well after the formation of the two barriers that currently separate those three allopatric populations. The planktonic larval duration of these species (35-49 days) and coastal pelagic habits may have facilitated dispersal by this genus across those dispersal barriers after they formed.

\section{Introduction}

Allopatric speciation is thought to result from two possible mechanisms: dispersal into separate regions, or the formation of a barrier that isolates populations as a vicariant event. In both cases, gene flow is eliminated and genetic differences accumulate over time, leading ultimately to speciation (Brown and Lomolino 1998; Coyne and Orr 2004). In the marine environment, many organisms, including nearly all bony reef fishes, have life histories that include a pelagic larval stage (Leis and McCormick 2002). During this phase, larvae are subjected to transport by ocean currents and are, thus, potentially widely dispersed. However, many barriers that eliminate or restrict gene flow have been identified in the marine environment. In the Atlantic ocean, those include two major breaks in adult habitat: the broad zone of Amazon-Orinoco discharge, and the deep expanse of ocean that forms the mid-Atlantic barrier (Briggs 1974; Floeter and Gasparini 2000; Rocha 2003; Floeter et al. 2008) (Fig. 1). Within this setting, both vicariance and dispersal have been described as driving population structure in marine organisms (e.g. Bernardi et al. 2003).

The Amazon discharge is thought to have begun acting as a biogeographic barrier to marine shore organisms, approximately 11 mya (Hoorn et al. 1995; Rocha 2003). 


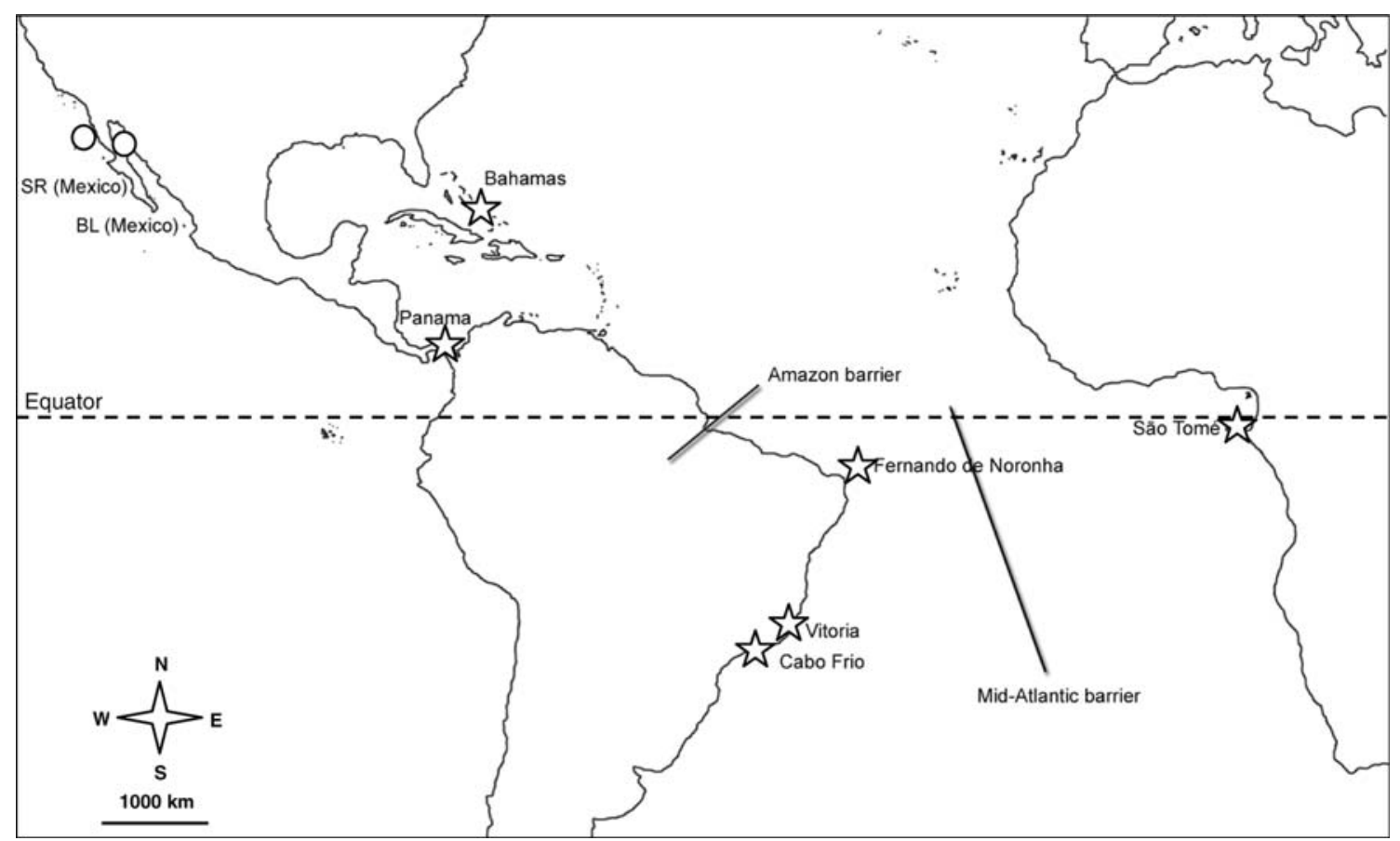

Fig. 1 Map of the collection sites with a schematic illustration of the biogeographic barriers. The Amazon barrier and mid-Atlantic barrier are indicated by thick straight lines. The origin of samples is indicated by stars. Clepticus: Bahamas, Panama, São Tome, Fernando de
Noronha, Vitória and Cabo Frio; outgroups are indicated by circles. Semicossyphus pulcher: Santa Rosalillita (SR, Mexico), and Bodianus diplotaenia Bahia de Los Angeles (BL, Mexico)

islands, and São Tomé indicate that Clepticus species are usually found between the surface to $40 \mathrm{~m}$ depth on seaward reef slopes and shallow patch reefs, and that their typical habitat is clear and often relatively turbulent water. Clepticus are plankton feeding species (Lieske and Myers 1994; personal observation of the authors). They spawn in the pelagic environment, forming breeding aggregations in open water (Robertson and Hoffman 1977; Allsop and West 2003). After hatching, larvae of $C$. parrae spend between 35 and 49 days in the pelagic environment before settling (Victor 1986).

The analyses by Floeter et al. (2008) of the relationships of pan-Atlantic fish species indicate that the level of connectivity is much greater across the Amazon barrier than across the mid-Atlantic barrier. Based on this pattern, we expected the Caribbean and Brazilian species to be more closely related than either of these is to the eastern Atlantic species. In contrast, morphological data suggest that the eastern Atlantic and Brazilian species are closer together than either of these is to their Caribbean counterpart (Heiser et al. 2000). Given the historical formation of the abovementioned barriers, the ecological characteristics of Clepticus and the morphological similarities of the species, the phylogenetic relationship within this group should provide insights into their evolutionary history and speciation patterns, as well as evaluate the effectiveness of the Amazon and mid-Atlantic barriers. 
We tested whether vicariance or dispersal promoted speciation in Clepticus by examining the timing of phylogenetic events relative to the ages of the Amazon and mid-Atlantic barriers. If vicariance drove speciation within this genus, then we would expect the timing of divergence between species to match the formation of the barriers. Whereas if dispersal is the evolutionary mechanism driving speciation in Clepticus, then the phylogenetic events would not correspond to the timing of the formation of those barriers.

\section{Materials and methods}

Samples of Clepticus were collected from the Caribbean, São Tomé (Gulf of Guinea) and Brazil. The closely related Semycossyphus and Bodianus species (Westneat and Alfaro 2005) were used as outgroups (Fig. 1). Immediately after collection, fin clips were placed in $95 \%$ ethanol and stored at ambient temperature in the field, and then at $4{ }^{\circ} \mathrm{C}$ in the lab. Total genomic DNA was prepared from $20 \mathrm{mg}$ of fin tissue by proteinase $\mathrm{K}$ digestion in lysis buffer $(10 \mathrm{mM}$ Tris, $400 \mathrm{mM} \mathrm{NaCl}, 2 \mathrm{mM}$ EDTA, 1\% SDS) overnight at $55^{\circ} \mathrm{C}$. This was followed by purification using phenol/chloroform extractions and alcohol precipitation (Sambrook et al. 1989).

Amplification of three mitochondrial genes was performed: (1) the Dloop using the universal primers CR-A and CR-E (Lee et al. 1995), (2) the mitochondrial 16S ribosomal RNA gene (16S) using 16SAR and 16SBR primers (Meyer 1993) and (3) the protein-encoding mitochondrial gene cytochrome $b$ (cytb) with Cyt1 and CB3H (Meyer 1993). Each $100 \mu \mathrm{l}$ reaction contained 10-100 ng of DNA, $10 \mathrm{mM}$ Tris- $\mathrm{HCl}$ (pH 8.3), $50 \mathrm{mM} \mathrm{KCl,} 1.5 \mathrm{mM} \mathrm{MgCl}_{2}$, 2.5 units of Taq DNA polymerase (Perkin-Elmer, Norwalk, CT, USA), $150 \mathrm{mM}$ of each dNTP and $0.3 \mathrm{mM}$ of each primer. It was amplified with a cycling profile of $45 \mathrm{~s}$ at $94^{\circ} \mathrm{C}, 1 \mathrm{~min}$ at $52^{\circ} \mathrm{C}$ and $1 \mathrm{~min}$ at $72^{\circ} \mathrm{C}$ for 35 cycles. The first intron of the nuclear $\mathrm{S} 7$ ribosomal protein was also amplified using the primers and protocols of Chow and Hazama (1998). Within an individual, we did not find any nuclear sequences with more than two polymorphisms that required cloning to resolve heterozygotic ambiguities. After purification of amplified DNA genes following the manufacturer's protocol (ABI, Perkin-Elmer), sequencing was performed on an ABI 3100 automated sequencer (Applied Biosystems, Foster City, CA, USA).

Clustal V implemented by Sequence Navigator (Applied Biosystems) was used to align the DNA sequences. Phylogenetic relationships were assessed by Maximum Parsimony (MP), Neighbour-Joining (NJ), and Bayesian methods implemented by the Software package PAUP (Phylogenetic Analyses Using Parsimony, version 4.0,
Swofford 2002) and MrBayes (version 2.1, Huelsenbeck and Ronquist 2001). Nucleotide sequence evolution models were evaluated using likelihood ratio tests implemented by Modeltest v.3.6 (Posada and Crandall 1998). Most parsimonious trees were obtained using a branch and bound search. Neighbour-joining reconstructions were based on substitution models obtained with Modeltest $(\mathrm{HKY}+\mathrm{I}+\mathrm{G}$ for mitochondrial genes and $\mathrm{HYQ}+\mathrm{G}$ for S7). Statistical confidence in nodes was evaluated using 2,000 non-parametric bootstrap replicates (Felsenstein 1985). MrBayes default settings for the Bayesian analysis were adopted including the GTR model (unequal base frequencies and six substitution rates). Stationarity of tree likelihood, sampled every 100 cycles, was consistently achieved after 2,100 generations and all sampled trees preceding stationarity were discarded. Topological differences were tested using a Shimodaira-Hasegawa test (Shimodaira and Hasegawa 1999) implemented by PAUP.

The time of divergence between species can be estimated using genetic divergence, or an estimate of coalescence time (Edwards and Beerli 2000). In both cases, mutations are assumed to proceed randomly and uniformly (molecular clock). Molecular clock enforcements were tested using a Shimodaira and Hasegawa test (Shimodaira and Hasegawa 1999) implemented by PAUP. Genetic divergence was estimated using distances based on substitution models obtained with Modeltest, for cytochrome $b$ alone. Indeed, cytochrome $b$ is the only locus where an estimate of substitution rate in fishes is generally accepted (McCune and Lovejoy 1998). In order to account for polymorphism in each species, divergence was estimated as the average pairwise distance between species minus the average pairwise distance within a species. Genetic divergence estimates, however, may slightly differ from the actual time of separation between species (see Edwards and Beerli 2000). Our data did not show any departure from a molecular clock $(P=0.209$ for cytochrome $b$ ) indicating that a molecular clock could not be rejected. In addition to a molecular clock, prior knowledge of mutation rates is necessary to estimate divergence times. In this study, we assumed a conservative sequence divergence rate of $0.5-2.6 \%$ per million year based on divergences calibrated for trans-Isthmian geminate damsel fishes (Chromis multilineata, C. atrilobata; Domingues et al. 2006) and grunts (Anisotremus virginicus, A. taeniatus; Bernardi et al. 2008), which encompasses the generally used fish universal rate of $1-2.5 \%$ per million year (McCune and Lovejoy 1998; Avise 2000).

\section{Results}

Dloop, cytochrome $b$ and $16 \mathrm{~S}$ were sequenced for 16 individuals (Table 1). Among Clepticus species, out of 1,520 bp 
Table 1 Location, code and number of samples of Clepticus and outgroups

\begin{tabular}{llll}
\hline & Location & Code & $\begin{array}{l}\text { Number } \\
\text { of samples }\end{array}$ \\
\hline C. parrae & Bahamas & BAH & 3 \\
& Panama & PAN & 1 \\
C. brasiliensis & Vitória (Brazil) & V & 3 \\
& Cabo Frio (Brazil) & CF & 1 \\
C. africanus & Fernando de Noronha (Brazil) & FN & 3 \\
Semicossyphus pulcher & São Tomé & ST & 3 \\
Bodianus diplotaenia & Santa Rosalillita (Mexico) & SR & 1 \\
& Bahia de Los Angeles (Mexico) & BL & 1 \\
\hline
\end{tabular}

for mitochondrial markers, $220 \mathrm{bp}$ were variable and $180 \mathrm{bp}$ were informative. As expected, the first intron of the nuclear S7 ribosomal protein was less variable, containing 16 variable positions among which 9 out of 452 bp were informative.

Phylogenetic relationships among the three Clepticus species based on the three mitochondrial markers (and for all reconstruction methods) were not significantly different (Shimodaira-Hasegawa tests, $P>0.05$ ). Therefore, the three mitochondrial data sets were combined. In contrast, since the data based on the nuclear intron of the ribosomal $\mathrm{S} 7$ protein was not congruent with the mitochondrial tree topology (Shimodaira-Hasegawa test, $P<0.05$ ), it was analysed separately.

Reconstructions based on mitochondrial loci (Fig. 2) resulted in a fully resolved phylogeny that separates Clepticus into three well-supported clades, corresponding to the three recognized species of Creole wrasses. The Caribbean species Clepticus parrae was in a sister position to the clade formed by the south Atlantic sister species $C$. brasiliensis and $C$. africanus (a clade supported by high bootstrap values and 51 shared mutations). Within the southern Atlantic clade, the groupings of individuals of $C$. brasiliensis and $C$. africanus were also supported by high bootstrap values, but with relatively few fixed differences ( 7 and 10 fixed differences for $C$. brasiliensis and $C$. africanus, respectively).

The nuclear tree was similar to the tree produced by mitochondrial markers with respect to the segregation between the Caribbean and the southern Atlantic species (Fig. 3), but with fewer sorting characters as expected. The southern Atlantic clade was characterized by only two fixed differences. However, within this clade, the two species (C. brasiliensis and C. africanus) did not exhibit any fixed differences.

Based on mitochondrial cytochrome $b$ sequences, and using the substitution model obtained using Modeltest $(\mathrm{HKY}+\mathrm{G})$, C. parrae and the southwestern and eastern Atlantic sister species were found to be $4.84 \%$ divergent, which corresponds to a range of divergence time of 9.681.86 mya. For the southwestern and eastern Atlantic clade (C. brasiliensis and C. africanus), pairwise sequence divergence is $0.3 \%$, suggesting that these species separated approximately between 0.60 and 0.12 mya.

\section{Discussion}

Phylogenetic relationships presented here are consistent with the general findings based on morphological characters, presented by Heiser et al. (2000). The shallow genetic separation of $C$. brasiliensis and $C$. africanus at the mitochondrial level and the lack of sorting for those two species at the nuclear locus suggest very recent speciation, which is consistent with the morphological similarity of these species. Indeed, Heiser et al. (2000) identified C. brasiliensis and $C$. africanus as sister species, based on (1) the presence of greatly elongated filaments on the caudal fins of those two species, but not in C. parrae, and (2) although colour patterns of males of the three species differed, those of the male $C$. brasiliensis and $C$. africanus were the most similar (Table 2).

The two major biogeographical barriers, the OrinocoAmazon outflow and the mid-Atlantic divide, clearly played an important role in speciation events in Clepticus.

I. The Amazon barrier evidently is much more permeable than the mid-Atlantic barrier. Floeter et al. (2008) analysis of its effects on reef fishes showed that (1) the level of co-occurrence of fish species between the Caribbean and Brazil is three times higher than that across the Atlantic; (2) sister species are also more commonly distributed between the Caribbean and Brazil than between the western Atlantic and the eastern. In addition, pelagic spawning fishes with medium to large body sizes are disproportionately able to cross this barrier. However, the genus Clepticus does not conform well to these general trends. The Amazon-Orinoco barrier evidently separated $C$. parrae and the southern 
Fig. 2 Phylogram for the genus Clepticus based on the mitochondrial control region, cytochrome $b$ and $16 \mathrm{~S}$ genes. Bootstrap support values are show for neighbour-joining/ maximum parsimony/likelihood, respectively. Origin of samples is indicated by labels as in Table 1

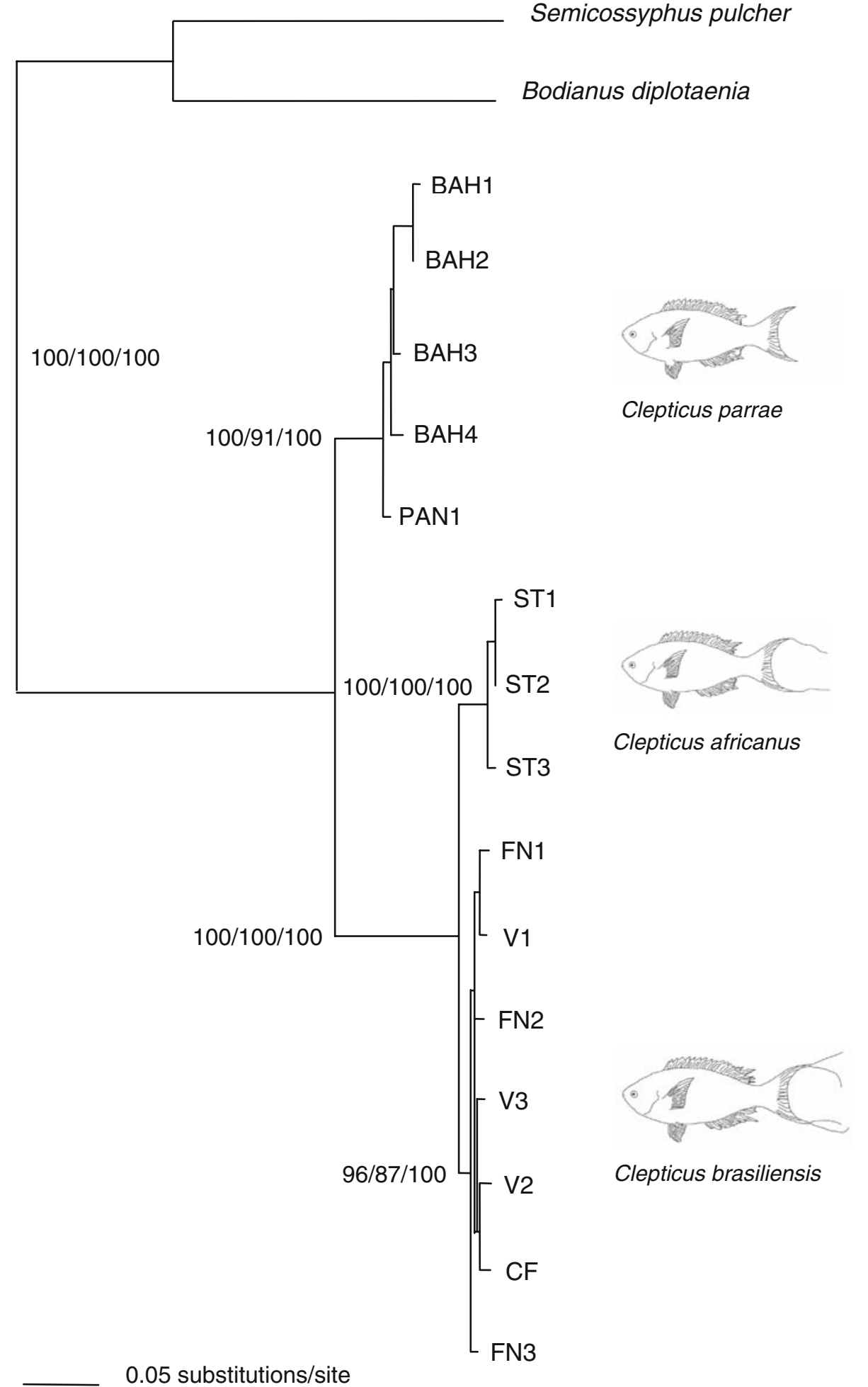

Atlantic lineage sometime after it formed $\sim 11$ mya, as the two populations diverged approximately by 9.68-1.86 mya.At first sight, Clepticus species would appear to have characteristics (semi-pelagic adult habits, moderately long pelagic larval duration) that should enhance dispersal and maintain long distance connectivity. Lack of suitable adult habitat within that barrier (cf Rocha et al. 2002) and clear water reefs in the case of Clepticus were likely involved in isolating $C$. parrae and the south-Atlantic lineage across this barrier. Clepticus has a sufficiently long pelagic larval stage (35 and 49 days for $C$. parrae) that currents 
Fig. 3 Phylogram for the genus Clepticus based on S7. In the phylogenetic tree bootstrap support values are show for neighbour-joining/maximum parsimony/likelihood,

respectively. Origin of samples is indicated by labels as in

Table 1

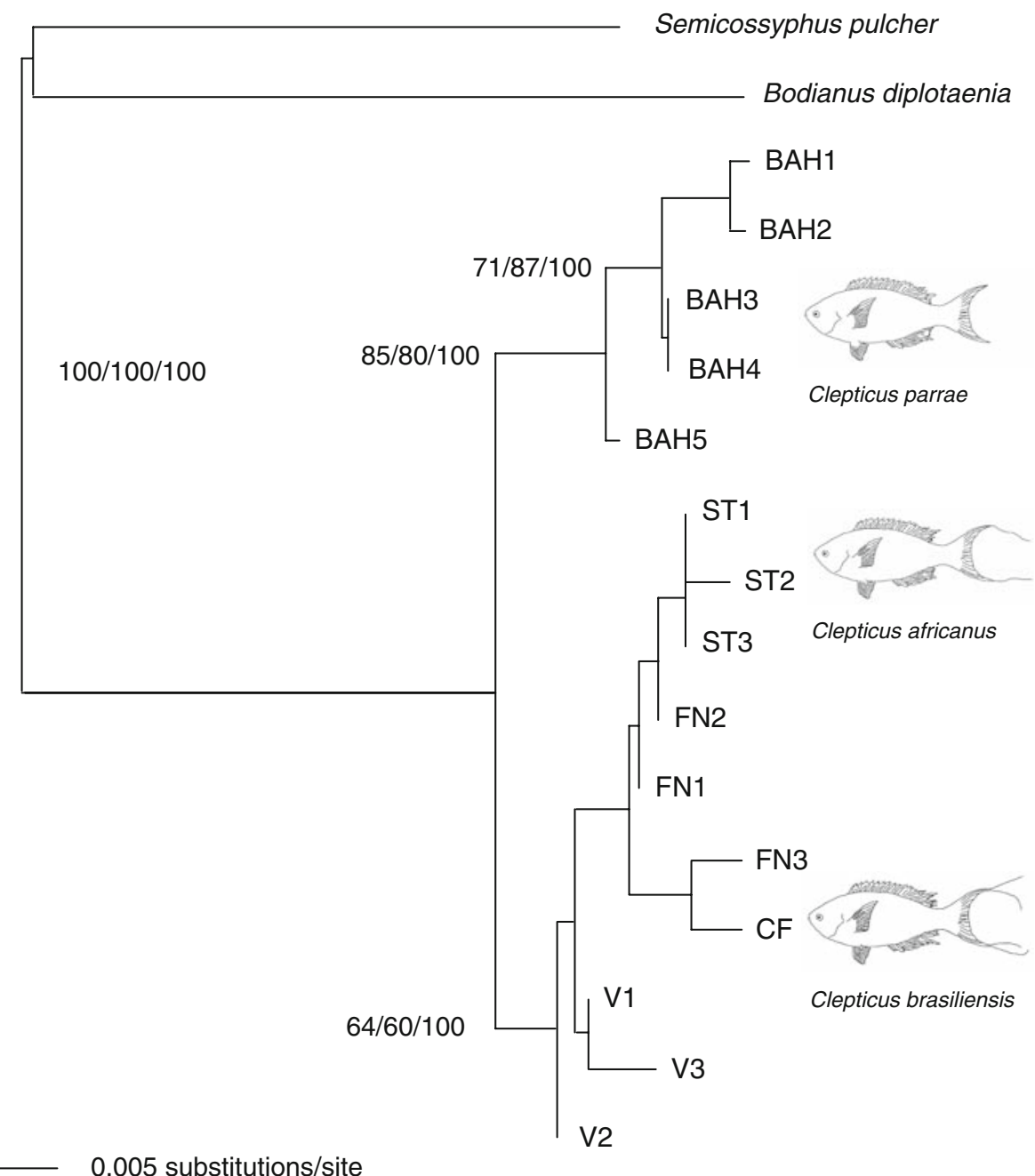

Table 2 Morphological and colouration differences between Clepticus parrae, C. africanus and C. brasiliensis

\begin{tabular}{lllc}
\hline & C. parrae & C. africanus & C. brasiliensis \\
\hline $\begin{array}{l}\text { Morphology } \\
\begin{array}{l}\text { Posterior margin } \\
\text { of fleshy opercular flap }\end{array}\end{array}$ & $\begin{array}{c}\text { Pointed above the } \\
\text { pectoral axil }\end{array}$ & $\begin{array}{c}\text { Bluntly pointed above } \\
\text { the pectoral axil }\end{array}$ & $\begin{array}{c}\text { Extends as a rounded } \\
\text { ear above the } \\
\text { pectoral axil }\end{array}$ \\
$\begin{array}{l}\text { Number of segmented } \\
\text { rays in the dorsal fin }\end{array}$ & 10 & $6-9$ & $6-8$ \\
$\begin{array}{l}\text { Number of segmented } \\
\text { rays in the anal fin }\end{array}$ & $12-13$ & $7-10$ & $7-11$ \\
$\begin{array}{l}\text { Uppermost and lowermost } \\
\text { branched caudal rays }\end{array}$ & No filaments & Single robust wire-like filament & Two or more wire-like \\
$\begin{array}{l}\text { Colour } \\
\text { Male body courtship colours }\end{array}$ & $\begin{array}{c}\text { Dark blue/purple front two-thirds, } \\
\text { orange-yellow rear one-third, } \\
\text { pinkish tail }\end{array}$ & $\begin{array}{c}\text { Blackish brown + broad } \\
\text { yellow saddle or bar } \\
\text { at the pectoral level }\end{array}$ & $\begin{array}{c}\text { Changeable: front } \\
\text { half light purple } \\
\text { and rear half yellow; } \\
\text { or entirely pale } \\
\text { pinkish-grey }\end{array}$ \\
\hline
\end{tabular}


should be able to carry pelagic juveniles across the Amazon-Orinoco barrier, in which likely transit times are in the order of 26-49 days (Muss et al. 2001). The lack of connectivity may therefore reflect the fact that turbid, reduced-salinity nearshore waters in that barrier are unsuitable for pelagic juveniles.

II. Due to the considerable age of the mid-Atlantic barrier (formation began $\sim 84$ mya), it is unlikely that a vicariant event would have separated trans-Atlantic lineages of Clepticus. Our data indicate that such is the case. The mid-Atlantic barrier is less permeable than the Amazon-Orinoco barrier to a broad range of reef fishes. Although some trans-Atlantic sister species do exist (Floeter et al. 2008) and a few species found on both sides of the mid-Atlantic barriers have well-connected populations (Bowen et al. 2006). Ecological characteristics, common to those species and Clepticus, are the relatively long pelagic larval durations and the potential for rafting of adult forms (Victor 1986; Floeter et al. 2008). This barrier appears to be most permeable between Brazil and the Gulf of Guinea (Floeter et al. 2008), perhaps due to the north equatorial current, which may be able to carry propagules in surface waters from northern Brazil to the Gulf of Guinea in as few as 35 days (see Muss et al. 2001). While an adequate larval duration and coastal pelagic adult habits might be expected to have promoted transAtlantic dispersal some time ago, and continued connectivity thereafter, it appears that such dispersal occurred only very recently and has led to two isolated populations. Due to inadequate sample sizes, we could not determine the directionality of the initial transAtlantic dispersal.

Our data add to the findings of previous studies that indicate a lack of consistent pattern of variation in the timing of cladistic events separating the Caribbean and south Atlantic sister taxa. If we consider the same sequence divergence rate of $0.5-2.6 \%$ per million years for the cytochrome $b$ locus, cladogenesis of Atlantic Ophioblennius (blennies) species between the Caribbean and Brazil occurred 6 mya (Muss et al. 2001), whereas the timing of separation between Caribbean and Brazilian species of Sparisoma (parrot fishes) was estimated around 2.2 mya (Robertson et al. 2006). Using the mitochondrial control region, Costagliola et al. (2004) estimated the time of separation between Thalassoma bifasciatum and $T$. noronhanum to be somewhere between 1.86 and 7.44 mya. Even within the same genus, Halichoeres, striking differences in genetic divergence have been found by Rocha (2004): H. maculipinna and $H$. penrosei (2.6-6.5 mya) and $H$. cyanocephalus and $H$. dimidiatus (0.9-2.3 mya). The divergence times calculated for Clepticus parrae and the southern Atlantic species pair (approximately $4.84 \%$ genetic divergence, which corresponds to 1.86-9.68 mya) falls well within these ranges. All of these events are more recent than the establishment of the Amazon barrier, around 11 mya (Hoorn et al. 1995). However, changing sea levels and river flow rates affected the intensity of sediment flows and the extent and depth of the freshwater plume over and near the continental shelf. Those changes may well have greatly affected the permeability of this barrier since it formed (Rocha 2003), intermittently allowing and then preventing the crossing of this barrier and so producing variability in the timing of isolation events across that barrier.

The finding of similar trends for other species, i.e. the mismatch of speciation time and the rise of the barrier emphasizes the need for further studies on permeability fluctuations of the Amazon-Orinoco system. Finally, the separation of the Brazilian-African pair is a very recent phenomenon (between 0.60 and 0.12 mya). The $3,500 \mathrm{~km}$ wide Atlantic barrier began to form $\sim 84$ mya, and must have been in its present state when that dispersal and separation event occurred between $C$ brasiliensis and $C$ africanus. Similarly, recent trans-Atlantic colonization events have been observed for Gnatholepis (Rocha et al. 2005) and Aulostomus (Bowen et al. 2001). While morphological and colour differences between incipient species are not always correlated with genetic differences (Bernardi et al. 2002; Craig et al. 2004; Rocha et al. 2007), it is interesting to note that for Clepticus even though the separation of the southern Atlantic species pair is such a recent event, there are already minor morphological and distinctive color differences distinguishing the two morpho-species (Table 2). While the morphological differences other than male courtship colours found between the three morpho-species of Clepticus may seem relatively minor, such situations commonly occur among labroid fishes, with sister species in many genera distinguished primarily on the basis of differences in male colour patterns.

This study highlights the varying permeability of different biogeographical barriers on evolutionary processes. Three different species are clearly separated by well-known biogeographical barriers; however, the timing of separation does not match the ages of the barriers, suggesting that vicariance was not the primary factor driving speciation in Clepticus. Instead, dispersal appears to have played the most important role in the speciation events in this genus. However, while we have identified the timing of speciation events due to migration across large-scale marine barriers in this genus, additional data will be necessary to determine where the genus originated and the direction of migration across the two barriers.

Acknowledgments We would like to thank Ken Clifton for collecting samples from San Blas, Panama, and Luiz Rocha and Suzanne 
Mills for reviewing the manuscript. R. Beldade was supported by a Foundation for Science and Technology grant (SFRH/BPD/26901/ 2006) and S.R. Floeter by a National Geographic Society grant (Grant \#7937-05).

Open Access This article is distributed under the terms of the Creative Commons Attribution Noncommercial License which permits any noncommercial use, distribution, and reproduction in any medium, provided the original author(s) and source are credited.

\section{References}

Allsop DJ, West SA (2003) Constant relative age and size at sex change for sequentially hermaphroditic fish. J Evol Biol 16:921929. doi:10.1046/j.1420-9101.2003.00590.x

Avise JC (2000) Phylogeography: the history and formation of species. Harvard University Press, Cambridge

Bernardi G, Holbrook SJ, Schmitt RJ, Crane NL, DeMartini E (2002) Species boundaries, populations, and colour morphs in the coral reef three-spot damselfish (Dascyllus trimaculatus) speciescomplex. Proc R Soc Lond 269:599-605. doi:10.1098/rspb.2001. 1922

Bernardi G, Findley L, Rocha-Olivares A (2003) Vicariance and dispersal across Baja California in disjunct marine fish populations. Evolution 57:1599-1609

Bernardi G, Alva-Campbell YR, Gasparini JL, Floeter SR (2008) Molecular ecology, speciation, and evolution of the reef fish genus Anisotremus. Mol Phylogenet Evol 48:929-935. doi:10.1016/j.ympev.2008.05.011

Bowen BW, Bass AL, Rocha LA, Grant WS, Robertson DR (2001) Phylogeography of the trumpet fish (Aulostomus spp.): ring species complex on a global scale. Evolution 55:1029-1039. doi:10.1554/0014-3820(2001)055[1029:POTTAR]2.0.CO;2

Bowen BW, Bass AL, Muss AJ, Carlin J, Robertson DR (2006) Phylogeography of two Atlantic squirrel fishes (Family Holocentridae): exploring links between pelagic larval duration and population connectivity. Mar Biol (Berl) 149:899-913. doi:10.1007/ s00227-006-0252-1

Briggs JC (1974) Marine zoogeography. McGraw-Hill, NewYork

Brown JH, Lomolino MV (1998) Biogeography. Sinauer Associates, Sunderland, MA

Chow S, Hazama K (1998) Universal PCR primers for S7 ribosomal protein gene introns in fish. Mol Ecol 7:1255-1256

Costagliola D, Robertson DR, Guidetti P, Stefanni S, Wirtz P, Heiser JB, Bernardi G (2004) Evolution of coral reef fish Thalassoma spp. (Labridae). 2. Evolution of the eastern Atlantic species. Mar Biol (Berl) 144:377-383. doi:10.1007/s00227-003-1200-y

Coyne JA, Orr HA (2004) Speciation. Sinauer Associates, Sunderland

Craig MT, Hastings PA, Pondella DJ (2004) Speciation in the Central American seaway: the importance of taxon sampling in the identification of trans-isthmian geminate pairs. J Biogeogr 31:10851091. doi:10.1111/j.1365-2699.2004.01035.x

Domingues VS, Santos RS, Brito A, Almada V (2006) Historical population dynamics and demography of the eastern Atlantic pomacentrid Chromis limbata (Valenciennes, 1833). Mol Phylogenet Evol 40:139-147. doi:10.1016/j.ympev.2006.02.009

Edwards SV, Beerli P (2000) Perspective: gene divergence, population divergence, and the variance in coalescence time in phylogeographic studies. Evolution 54:1839-1854

Felsenstein J (1985) Confidence limits on phylogenies: an approach using the bootstrap. Evolution 39:783-791. doi:10.2307/2408678

Floeter SR, Gasparini JL (2000) The southwestern Atlantic fish fauna: composition and zoogeographic patterns. J Fish Biol 56:10991114. doi:10.1111/j.1095-8649.2000.tb02126.x
Floeter SR, Rocha LA, Robertson DR et al (2008) Atlantic reef fish biogeography and evolution. J Biogeogr 35:22-47

Heiser JB, Moura RL, Robertson DR (2000) Two new species of Creole wrasse (Labridae: Clepticus) from opposite sides of the Atlantic Aqua. J Ichthyol Aquat Biol 4:67-76

Hoorn C, Guerrero J, Sarmiento GA, Lorente MA (1995) Andean tectonics as a cause for changing drainage patterns in Miocene northern South America. Geology 23:237-240. doi:10.1130/ 0091-7613(1995)023<0237:ATAACF>2.3.CO;2

Huelsenbeck JP, Ronquist F (2001) Mrbayes: Bayesian inference of phylogeny. Bioinformatics 17:754-755. doi:10.1093/bioinformatics/17.8.754

Lee WJ, Conroy J, Howell WH, Kocher TD (1995) Structure and evolution of teleost mitochondrial control regions. J Mol Evol 41:5466. doi:10.1007/BF00174041

Leis JM, McCormick MI (2002) The biology, behavior and ecology of the pelagic larval stage of coral reef fishes. In: Sale P (ed) Dynamics and diversity in a complex ecosystem. Academic Press, San Diego, pp 171-200

Lieske E, Myers R (1994) Collins pocket guide. Coral reef fishes: IndoPacific and Caribbean including the Red Sea. Harper \& Collins, Princeton

McCune AR, Lovejoy NR (1998) The relative rate of sympatric and allopatric speciation in fishes: tests using DNA sequence divergences between sister species and among clades. In: Howard DJ, Berlocher SH (eds) Endless forms: species and speciation. Oxford University Press, New York, pp 132-153

Meyer A (1993) Evolution of mitochondrial DNA in fishes. Biochemistry and molecular biology of fishes, vol 2. Molecular biology frontiers. In: Hochachka PW, Mommsen TP (eds) 2.3 Phylogenetic analyses and population structure. Elsevier, Amsterdam, pp $1-38$

Muss A, Robertson DR, Stepien CA, Wirtz P, Bowen BW (2001) Phylogeography of Ophioblennius: the role of ocean currents and geography in reef fish evolution. Evolution 55:561-572. doi:10.1554/0014-3820(2001)055[0561:POOTRO]2.0.CO;2

Pittman WCIII, Cande S, LaBrecque J, Pindell J (1993) Fragmentation of Gondwana: the separation of Africa from South America. In: Goldblatt P (ed) Biological relationships between Africa and South America. Yale University Press, New Haven, pp 15-34

Posada D, Crandall KA (1998) Model test: testing the model of DNA substitution. Bioinformatics 14:817-818. doi:10.1093/ bioinformatics/14.9.817

Randall JE (1996) Caribbean reef fishes, 3rd edn. TFH, Neptune City

Robertson DR, Hoffman SG (1977) The roles of female mate choice and predation in the mating systems of some tropical labroid fishes. Z Tierpsychol 45:298-320

Robertson DR, Karg F, Moura RL, Victor BC, Bernardi G (2006) Mechanisms of speciation and faunal enrichment in Atlantic parrot fishes. Mol Phylogenet Evol 40:795-807. doi:10.1016/ j.ympev.2006.04.011

Rocha LA, Bass AL, Robertson DR, Bowen BW (2002) Adult habitat preferences, larval dispersal, and the comparative phylogeography of three Atlantic surgeon fishes (Teleostei: Acanthuridae). Mol Ecol 11:243-252. doi:10.1046/j.0962-1083.2001.01431.x

Rocha LA (2003) Patterns of distribution and processes of speciation in Brazilian reef fishes. J Biogeogr 30:1161-1171. doi:10.1046/ j.1365-2699.2003.00900.x

Rocha LA (2004) Mitochondrial DNA and color pattern variation in three western Atlantic Halichoeres (Labridae), with the revalidation of two species. Copeia 2004:770-782. doi:10.1643/CG-04106

Rocha LA, Robertson DR, Rocha CR, Van Tassell JL, Craig MT, Bowen BW (2005) Recent invasion of the tropical Atlantic by an Indo-Pacific coral reef fish. Mol Ecol 14:3921-3928. doi:10.1111/j.1365-294X.2005.02698.x 
Rocha LA, Craig MT, Bowen BW (2007) Phylogeography and the conservation of coral reef fishes. Coral Reefs 26:501-512. doi:10.1007/s00338-007-0261-7

Sambrook J, Fritsch EF, Maniatis T (1989) Molecular cloning: a laboratory manual, 2nd edn. Cold Spring Harbor Laboratory, Cold Spring Harbor

Shimodaira H, Hasegawa M (1999) Multiple comparisons of loglikelihoods with applications to phylogenetic inference. Mol Biol Evol 16:1114-1116
Swofford DL (2002) PAUP*: phylogenetic analyses using parsimony (*and other methods), Version 4. Sinauer Associates, Sutherland Victor BC (1986) Duration of the planktonic larval stage of one hundred species of Pacific and Atlantic wrasses (family Labridae). Mar Biol (Berl) 90:317-326. doi:10.1007/BF00428555

Westneat MW, Alfaro ME (2005) Phylogenetic relationships and evolutionary history of the reef fish family Labridae. Mol Phylogenet Evol 36:370-390. doi:10.1016/j.ympev.2005.02.001 